\title{
Pengaruh Seleksi terhadap Sifat Reproduksi Puyuh (Coturnix coturnix japonica)
}

\author{
Desia Kaharuddin ${ }^{1 *}$ dan Kususiyah ${ }^{1}$ \\ ${ }^{1}$ Jurusan Peternakan Fakultas Pertanian Universitas Bengkulu \\ Jalan W.R. Supratman, Kandang Limun, Bengkulu 38371 \\ *Penulis Korespondensi: desiakaharuddin6@gmail.com
}

Artikel ini diterima (received): 30 Mei 2021; dinyatakan disetujui (accepted): 31 Mei 2021; terbit (published): 31 Mei 2021. Artikel ini dipublikasi secara daring pada https://ejournal.unib.ac.id/index.php/buletin_pt/index

\begin{abstract}
Abstrak
Penelitian ini bertujuan untuk mengevaluasi pengaruh seleksi berdasarkan berat badan umur $4 \mathrm{mg}$ terhadap sifat reproduksi dan produksi puyuh Generasi 1 dan Generasi 2. Penelitian ini dilaksanakan di kandang unggas Jurusan Peternakan Fakultas Pertanian Universitas Bengkulu. Materi dasar yang digunakan adalah puyuh lokal jantan asal Payakumbuh dan betina asal Bengkulu. Hasil persilangannya dinamakan puyuh parental yang akan menghasilkan puyuh G1. Pada umur empat minggu puyuh G1 diseleksi berdasarkan berat badan pada umur empat minggu. $60 \%$ puyuh betina tertinggi dan $20 \%$ puyuh jantan tertinggi digunakan sebagai tetua untuk generasi berikutnya seleksi dilakukan sampai generasi ketiga. Data yang diperoleh dianalisis secara deskriptif. Hasil penelitian ini menunjukkan bahwa performa reproduksi puyuh yang diseleksi pada umur empat minggu, fertilitasnya puyuh G1 - G6 lebih dari puyuh parental $91,74 \%$ dengan daya tetas $88,50 \%$, rataan berat telur tetas $11,21 \pm 0,57 \mathrm{~g}$ dengan berat tetas $6,53 \pm 0,43 \mathrm{~g}$. Seleksi juga meningkat performans pertumbuhan, Berat badan puyuh umur 2, 4 dan 6 minggu yang diseleksi umur empat minggu $43,12 \pm 5,23 ; 85,32 \pm 6,75$ dan 116,34 $\pm 3,51$ dengan pertambahan berat badan umur 2,4 dan 6 minggu berturut-turut adalah $33,34 \pm 4,31 ; 42,20 \pm 4,80$ dan $31,02 \pm 2,16$. Dari hasil penelitian ini dapat disimpulkan bahwa seleksi dapat meningkat performa reproduksi pada puyuh.
\end{abstract}

Kata kunci : seleksi, reproduksi, fertilitas dan daya tetas

\section{Pendahuluan}

Dewasa ini ternak puyuh mengalami penurunan kualitas genetic, penyebabnya antara lain adalah system pemeliharaan dan manajemen pembibitan yang tidak mengikuti prosedur yang tepat sehingga kualitas bibit yang dipelihara tidak menunjukkan produksi yang optimal. Oleh karena itu, dalam rangka mempertahankan kemurnian ternak sekaligus meningkatkan performans genetic keturunannya perlu segera dilakukan perbaikan mutu genetic ternak, dengan berbagai cara diantaranya adalah melalui seleksi.

Seleksi merupakan proses membiarkan ternak-ternak yang memiliki gen-gen (breeding value) yang baik untuk bereproduksi, sehingga generasi berikutnya mempunyai gen yang lebih baik dari generasi sebelumnya (Warwick et al. 1990; BeBreeder, 2002). Seleksi biasanya dilakukan pada sifat-sifat kuantitatif yang mempunyai nilai ekonomis tinggi. Sifat fenotipik adalah tampilan individu yang tampak dari luar dan dapat dibedakan atas sifat kualitatif dan sifat kuantitatif (Hardjosubroto, 2001).

Pelaksanaan program seleksi akan efektif apabila telah diketahui parameter genetic dan fenotip, seperti nilai pemuliaan atau estimation breeding value ( EBV). Menurut Bourdon (1997) apabila nilai pemuliaan masing-masing ternak diketahui dengan pasti maka penentuan peringkat ternak berdasarkan nilai pemuliaan sesungguhnya dalam dapat dilakukan dengan mudah. 
Menurut Suzuki et al. (1989) keberhasilan seleksi sifat kuantitatif dipantau melalui perhitungan respon seleksi antar generasi pada masing-masing peubah. Nilai respon seleksi yang tinggi menggambarkan besarnya peranan seleksi yang dilaksanakan program pemuliaan. Menurut Lin et al. (2006) seleksi berat badan tidak hanya mempertimbangkan terjadinya perbaikan efisiensi pakan, tetapi juga dihubungkan dengan peningkatan ketahanan terhadap lingkungan tropis.

Respon seleksi adalah perubahan nilai ratarata fenotipe dari generasi berikutnya, sebagai akibat dari adanya seleksi terhadap populasi. Respon seleksi (R) merupakan kenaikan mutu genetic ternak yang dinyatakan dengan simbul $\Delta G$ yang melambangkan perubahan $(\Delta)$ dari nilai genetic (G) (Hardjosubroto, 1994). Respon seleksi menjelaskan perubahan antargenerasi yang linear, diikuti dengan penurunan respon sampai batas seleksi tercapai (Reddy, 1996). Menurut Hardjosubroto (1994), tidak seluruh perbedaan performans diturunkan ke generasi selanjutnya, proporsi dari difrensial seleksi yang dapat diwariskan kepada generasi berikutnya adalah yang bersifat genetik saja, yaitu sebesar nilai heritabilitas.

Penelitian ini bertujuan untuk mengevaluasi pengaruh seleksi berdasarkan berat badan umur $4 \mathrm{mg}$ terhadap sifat reproduksi dan produksi puyuh Generasi 1 dan Generasi 2. Diduga seleksi meningkatkan performa reproduksi puyuh.

\section{Bahan dan Metode}

Penelitian ini dilakukan di kandang unggas jurusan Peternakan Fakultas Pertanian Universitas Bengkulu. Hasil persilangan antara puyuh jantan local asal Payakumbuh dan puyuh betina asal Bengkulu merupakan populasi dasar yang diseleksi pada umur 4 dan 6 minggu berdasarkan berat badan. Seleksi dilakukan berdasarkan $60 \%$ berat badan tertinggi untuk betina dan $20 \%$ tertinggi untuk jantan, digunakan sebagai tetua generasi berikutnya (G1). Setelah masing-masing puyuh hasil seleksi (G1) berproduksi minimal 50\% maka telurnya ditetaskan untuk menghasilkan puyuh generasi seleksi berikutnya (G2)

Puyuh G1 yang diseleksi umur 4 minggu akan menjadi tetua puyuh $\mathrm{G} 2$ sedangkan puyuh
G2 diseleksi dengan cara yang tetua G3 begitu seterusnya sampai G6. Setiap generasi dilakukan pengamatan sifat-sifat reproduksi dan produksi.

Variabel yang diamati untuk sifat reproduksi adalah; berat telur tetas, fertilitas, dayatetas, berat tetas, embrio mati sedangkan untuk sifat produksi adalah berat badan dan pertambahan berat badan umur 2, dan 4 minggu. Untuk variable produksi yang diamati adalah berat badan dan pertambahan berat badan umur 2 dan 4 minggu.

Data reproduksi dan produksi dianalisis secara deskriptif sedangkan parameter genetic dihitung menggunakan rumus dari Hardjosubroto (1994).

Perbedaan antara rataan performans ternak yang terseleksi dengan rataan performans populasi sebelum diadakan seleksi dinamakan difrensial seleksi (Hardjosubroto, 1994).

$$
S=X s-X
$$

dimana:

$$
\begin{aligned}
& S=\text { diffrensial seleksi } \\
& X=\text { rataan populasi sebelum seleksi } \\
& X S=\text { rataan populasi sesudah seleksi }
\end{aligned}
$$

Untuk menghitung respon seleksi digunakan rumus menurut Falconer; 1981 dan Hardjosubroto, 1994) yaitu:

$$
R=h 2 . S \text {. }
$$

dimana:

$$
\begin{aligned}
& \mathrm{R}=\text { respon seleksi } \\
& \mathrm{h} 2=\text { heretabilitas sifat yang diseleksi } \\
& \mathrm{S}=\text { diffrensial seleksi }
\end{aligned}
$$

Selama penelitian air minum diberikan ad libitum, ransum yang digunakan pada penelitian ini dua macam yaitu ransum starter 0-6 minggu protein 23\% dan Energi $3200 \mathrm{kkal}$ dan ransum layer dengan protein 20\% EM 3000 kkal.

\section{Hasil dan Pembahasan}

Performa reproduksi puyuh yang diseleksi berdasarkan berat badan pada umur empat dan enam minggu disajikan pada Tabel 1 . Seleksi berat badan pada umur empat dan enam minggu terjadi peningkatan berat telur tetas dibandingkan berat tetur tetas tetua. Tabel 1 menunjukkan bahwa berat telur tetas seleksi berat badan umur empat minggu lebih 
ringan dari berat telur tetas hasil seleksi berat badan umur enam minggu baik pada G1 maupun pada G2.

Faktor-faktor yang menentukan berat telur selain genetik adalah berat badan dan umur induk. Perbedaan berat telur bisa saja disebabkan oleh badan induk yang beragam. Menurut Prasetyo (2006) semakin beragam berat badan induk yang berada pada satu kelompok makin beragam juga berat telur yang dihasilkan. Hermawan (2000) menyatakan bahwa berat telur tetas dapat digunakan untuk memprediksi berat tetas.

Berdasarkan Tabel 1 terlihat bahwa fertilitas telur puyuh hasil seleksi lebih tinggi dari puyuh tetua namun seleksi berat badan setiap generasi nilai fertilitas telurnya cenderung menurun, faktor yang mempengaruhi fertilitas adalah sex ratio, umur ternak, jarak waktu kawin sampai bertelur dan musim saat berproduksi (Suprijatna et al. 2005). Nilai fertilitas telur puyuh hasil seleksi lebih tinggi dari yang dilaporkan Kaharuddin (2007).

Daya tetas telur puyuh hasil seleksi untuk semua generasi (G1-G6) lebih tinggi dari puyuh parental apabila dibandingkan sesame puyuh hasil sleksi daya tetas cenderung meningkat kecuali daya tetas telur puyuh G4 dan G6. Menurut Sa'diah et al. (2015) daya tetas telur dipengaruhi oleh teknis seleksi telur tetas dan teknis operasional pelaksanaan penetasan. Hasil yang didapat pada penelitian ini lebih tinggi dari hasil penelitian Kaharuddin (2007).
Berat telur tetas setiap generasi menunjukkan peningkatan kecuali seleksi pada generasi 1 (G1) belum mampu menghasilkan telur tetas yang lebih besar dari stock dasar, G2 berhasil meningkatkan berat telur 0,03 g dari stock dasar dan dari tetuanya G1 berhasil meningkatkan berat telur sebanyak 0,11 g. Peningkatan yang tinggi ditunjukkan generasi tiga $\mathrm{G} 3$ yaitu $0,15 \mathrm{~g}$ dari $\mathrm{G} 2$, dan 0,26 dari $\mathrm{G} 1$ sedangkan dengan stock dasar peningkatannya sebanyak 0,18 g.

Berdasarkan Tabel 1 terlihat setiap generasi dapat meningkatkan fertilitas dan fertilitas telur tertinggi ditunjukkan puyuh hasil seleksi G3 yaitu $91,63 \%$. Fertilitas telur puyuh hasil seleksi pada penelitian lebih tinggi daripada fertilitas telur puyuh hasil persilangan antara puyuh asal Padang, Bengkulu dan Yogyakarta (77,50-89,05 $\%)$ yang dilaporkan Kaharuddin dan Kususiyah (2006).

Tabel 1 menunjukkan bahwa seleksi dayatetas, setiap generasi memperlihatkan peningkatan daya tetas dan daya tetas tertinggi ditunjukkan oleh generasi ketiga (G3). Kaharuddin (2007) melaporkan bahwa daya tetas telur puyuh di peternakan rakyat kota Bengkulu berkisar antara $65,47-87,15 \%$.

\section{Kesimpulan}

Dari hasil penelitian ini dapat disimpulkan bahwa seleksi dapat meningkat performan reproduksi dan produksi pada puyuh.

Tabel 1. Performa reproduksi puyuh hasil seleksi umur 4 dan 6 minggu

\begin{tabular}{lccccc}
\hline \multirow{2}{*}{ Variabel } & Tetua & \multicolumn{2}{c}{ G1 hasil seleksi berat badan } & G2 hasil seleksi berat badan \\
\cline { 3 - 6 } & & $G 1_{4}$ & $\mathrm{G} 1_{6}$ & $\mathrm{G} 2_{4}$ & $\mathrm{G} 2_{6}$ \\
\hline $\begin{array}{l}\Sigma \text { telur tetas } \\
\text { (butir) }\end{array}$ & 410 & 255 & 242 & 259 & 250 \\
BTT (g) & $11,01 \pm 0,32$ & $11,12 \pm 0,36$ & $11,30 \pm 0,25$ & $11,15 \pm 0,30$ & $11,46 \pm 0,27$ \\
Fertilitas (\%) & 81,44 & 82,35 & 92,56 & 85,33 & 91,20 \\
Daya tetas (\%) & 68,24 & 78,57 & 80,80 & 81,45 & 84,21 \\
\hline
\end{tabular}

Ket: $\mathrm{BTT}=$ berat telur tetas; $\mathrm{G1}_{4}=\mathrm{G} 1$ seleksi $\mathrm{BB}$ umur $4 \mathrm{mg} ; \mathrm{G} 1_{6}=\mathrm{G} 1$ seleksi $\mathrm{BB}$ umur $6 \mathrm{mg}$; $\mathrm{G}_{4}=\mathrm{G} 2$ seleksi $\mathrm{BB}$ umur $4 \mathrm{mg} ; \mathrm{G} 2_{6}=\mathrm{G} 2$ seleksi $\mathrm{BB}$ umur $6 \mathrm{mg}$ 


\section{Daftar Pustaka}

BeBreeder. 2002. Poultry Breeding /Genetics Is purebred the answer.www. uoguelph.ca/cgil/page $8 \mathrm{html}, 17$ May 2002Bourdon, R.M. 1997. Understanding Animal Breeding. Prentice Hall, Upper Saddle River, N.J.07458

Bourdon, R. M. 1997. Understanding Animal Breeding. Prentice Hall. Upper Saddle River, New Jersey, USA.

Falconer, D.S. 1981. Introduction Quantitative Genetics. $2^{\text {nd }}$ Ed. LongmB Group Ltd. London and New York.

Hardjosubroto, P. S. 1994. Aplikasi Pemuliaan Ternak di Lapangan. Grasindo, Jakarta.

Hardjosubroto, P. S. 2001. Konservasi Ternak Asli. Fakultas Peternakan, IPB, Bogor.

Hermawan, A. 2000. Pengaruh bobot dan indeks telur terhadap jenis kelamin anak ayam kampung pada saat menetas. Skripsi. Fakultas Peternakan, IPB, Bogor.

Lin, H., H.C. Jiao, J. Buyse and E. Decuypere. 2006. Strategies for preventing heat stress in poultry. World's Poult. Sci. J. 62: 71-85.

Kaharuddin, D. 1989. Pengaruh bobot telur tetas terhadap bobot tetas, daya tetas, Pertambahan berat badan dan angka kematian sampai umur empat minggu pada puyuh (coturnix-coturnix japonica). Laporan Penelitian Universitas Bengkulu. Bengkulu.

Kaharuddin, D dan Kususiyah. 2006. Performans sifat kualitatif dan kuantitatif puyuh asal Yogyakarta, Padang dan Bengkulu. Jurnal Sain Peternakan Indonesia, 1 (1): 21-25.

Kaharuddin, D. 2007. Performans puyuh hasil pembibitan peternakan rakyat di kota Bengkulu, Edisi Khusus, No. 3. Jurnal Ilmuilmu Pertanian Indonesia.

Prasetyo, L.H. 2006. Strategi dan peluang pengembangan pembibitan ternak itik. Wartazoa. 16 (3): 109-115.

Reddy R.P. 1996. Symposium : The effect of long-term selection on growth of poultry. Poultry Sci. 75: 1164-1167.

Sa'diah, I.N., D. Garnida dan A. Mushawwir. 2015. Mortalitas embrio dan daya tetas itik lokal (Anas sp.) berdasarkan pola pengaturan temperatur mesin tetas.J. Poult. Sci. 4(3):1-12.

Suzuki, D.T., A.J.F. Griffiths, J. H. Miller and R.C. Lewontin. 1989. An Introduction to Genetic Analysis. $4^{\text {th }}$ Ed. WH Freeman and Company, New York.

Suprijatana, E. U., Atmomarsono dan R. Kartasudjana. 2005. IImu Dasar Ternak Unggas. Panebar Swadaya, Jakarta.

Warwick, E. J., W. Astuti dan W. Hardjosubroto. 1990. Pemuliaan Ternak. Gadjah Mada University Press. Yogyakarta 